THE HISTORY AND DEVELOPMENT OF SAND COUNTR Y

\author{
J. D. EASTON \\ Farmer, Waitarere, Levin
}

In 1920, early Horowhenua settler, Rod McDonald, in his book Te Hekinga wrote: "From $300 \mathrm{ft}$ Moutere, the highest sandhill on the coast, the whole run could be surveyed - not the run to be seen now, sand for a mile or more inland from the beach, but grassed hills and flats inside the one littoral dune." He was referring to grassed dunes in 1870 - raw sand in 1920 - the resuits of bad grazing practices and strong westeriy winds.

My farming life has been spent in the Horowhenua County on coastal sand country near Waitarere Beach, halfway between Foxton and Levin. The area is fairly typical of that large sweep of land extending north from Paekakariki to south Taranaki on the west coast of the North Island, and varying in distance inland from 1 to $16 \mathrm{~km}$. This paper discusses experiences on my property and observations made of the practices of other sand country farmers.

The winds do blow harshly and often, and are an important factor to consider at all times in the development and use of the country. Because the terrain has been so influenced by wind, drainage is a problem. Water flow has not played the major part here that it has on the topography of so much of the rest of New Zealand. Large, law-lying areas are landlocked by dunes and early maps show numerous lakes and lagoons, many of which have now been drained by man who has created some real works of art as he has sent this water on its way to the sea. One drain near my place was dug by a Chinese labour force in the early 1920s; the drain is 3 to $4 \mathrm{~m}$ deep in places, and the bottom metre boxed with $50 \mathrm{~mm}$ totara slabs. Other lagoons have been filled by wind erosion, and in more modern times with the bulldozer.

The area was farmed in large sheep runs until the early 1900s. The carrying capacity was about 2 sheep/ha, and except for a few pockets no intensive development took place. It must have looked very easy country to those early settlers when they compared it with the heavy bush-clad country further inland. It was bought cheaply and in large blocks. When subdivision took place some dairy units of only 17 ha were established, together with sheep farms as large as 1700 ha. 
The natural cover was danthonia, tussock, and areas of flax and bracken. Sand breaks caused by overstocking at certain times, or by rabbits, were soon enlarged by the wind and required fencing and planting in trees; often marram grass, lupin, or buffalo grass was used as well to get a quick cover. A forest was planted along the coast in the early 1930s by the Public Works Department,

My father, who was born in Foxton 100 years ago, told me that a lot of the land north of there was cropped yearly to provide oats and chaff for the thousands of horses working inland making roads, railways, stopbanks, clearing bush, and cultivating land. The railway passed through that area and this early "mining" of the land by cropping could be the reason for the lower fertility still apparent there today.

After the 1939-45 war I went to work on my 100 ha propertybefore this it had been used for 6 years as a winter run-off by an inland dairy farmer, and before that it was used by an extensive sheep and cattle grazier. The vegetation on the farm was sweet vernal, danthonia, Yorkshire fog, tall fescue, trefoil, rushes and lupic. The farm was then in three paddocks which met at a corner. Here there was a $30 \mathrm{~m}$ well, complete with 9000 litre tank, three water troughs, and a petrol engine with a fly-wheel, which seemed to go only when, in temper, I threw the crank handle at it. Only 4 ha of the property had been ploughed and a crop of choumoellier and swedes taken. There were three large sandblow areas planted in macrocarpa. I had been trained as a shepherd but was manpowered to the farm, to dairy, on my return. Naturally enough I built the smallest cowshed I could, as I intended to remain in dairying only until I could be freed of the manpower law. I am still dairy farming, in-bred I suppose. My great-grandmother was milking cows and selling milk at Oriental Bay, Wellington, in 1842.

A neighbour told me, "A summer crop of turnips in before the 16th October or else", and "Touch the sand ridges and they'll blow away". There was a low sand ridge in the first area to be ploughed, and as I struck out with my two horses and single furrow lever plough, I was determined to lift the plough a little and stay well in the black soil. That decision has stood the test of time, and is still important in all sand country development. There is a covering of black soil from 130 to $200 \mathrm{~mm}$ deep over the flats, ridges, and hills, and I have found it quite safe to work in this material and have never had a blow or failed to establish a pasture in 30 years. After the first crop of turnips 
was fed off, the paddock was worked to a fine seedbed. The finer it got the softer it got, and here was lesson number two - consolidation. Since then, land-levelling preparation has been done in spring before sowing a crop, and only enough tillage to cover seed is done at pasture sowing in autumn.

Subdivision of the farm was a continuing thing, with farm races going all over the place to try to keep the lower areas separate from the higher ground. One did not borrow for development in those days, and as all improvements had to come from income it was the easier areas that one concentrated on. The

100 ha is made up of 48 ha of high sand ridges, 20 ha of low ridges and sandfiats, and 32 ha of swamps consisting of from 230 tc $375 \mathrm{~mm}$ of peat over sand.

This type of development went along until about 1952 when it was my good fortune to be invited to join the first dairy farm discussion group being formed. Maurice Rolston, a dairy farmer at Levin, Don Johnston, the Dairy Board Consulting Officer, and the late John Hopkins of the Department of Agriculture were responsible. These men and other farmers really helped me. I found others also had problems, and there was no longer such a shamed feeling when things did not go as well as one had hoped. Farmers have much going for them these days; there are answers to most dairy farming problems, but the decision must always be made by the farmer.

The late Charles Hamblyn of the Department of Agriculture came to the first farm discussion group visit on my farm. "Boy," he said, "fence the farm in rectangular paddocks and with a straight race. A bit of hill in a low paddock is all right, the cows will eat on the flat then rest on the hill, and thus transfer the fertility." These words used are mine; the words Charlie used were for the back paddock and expressed in terms not to be forgotten. The fences came down and a road grader put in a straight race $7 \mathrm{~m}$ wide and metalled at $6 \mathrm{~m}$, with $7 \mathrm{~m}$ gateways to $2 \mathrm{ha}$ paddocks. I have never regretted making that decision. Easy access and stock control were the result. This is typical of the non-textbook things learned at a farm. discussion group.

The swamp areas, covered mainly in tall fescue and rushes, were ploughed by a contractor with a crawler tractor and the largest plough in the district. A man walked behind the plough to lift every piece of timber, and the fescue was buried so deep that it could be forgotten. A flat, deep furrow was our aim.

As the low ridges, sandflats and swamps developed, the higher sand ridges remained, These were then worked in 6 to 8 ha 
blocks. The herd wintered on the area so that at the end of June to mid-July most of the old turf was broken, and there was a good plaster of cow-dung. An experienced crawler operator was engaged to giant disc it. The ridges, being sandblown, were sloping from the west, and were steeper on the eastern end. On some of the northern faces there was ratstail, and experience showed it was wiser to leave these areas alone because there is only raw, brown, dry sand under ratstail. It was easier to climb from the west end and wherever possible to disc obliquely along a face - the discs made almost as good a job as a plough. I learned early that it is far easier to disc a hill the first time than it is a second time. The disced area was left after one cut until mid-September when it was tandem-disced, levelled with a railway iron, and sown to turnips with $625 \mathrm{~kg}$ serpentine superphosphate/ha. In the following autumn it was sown to pasture with the minimum of cultivation and with fertilizer as much as could be paid for or booked.

Some aspects will now be dealt with more specifically.

\section{THE CLIMATE}

Strong westerly winds, a summer drought and very heavy frosts are the worst features - frosts can occur in February and October.

The average rainfall is $840 \mathrm{~mm}$, but it can vary from 750 to $1200 \mathrm{~mm}$ and there is no regular pattern. Often there is too little in summer with too much in winter.

\section{DRAINAGE}

Vee drains formed at cultivation time are ideal. They can be 'formed and sown with the paddock so that a mower or any other implement can cross them. Spintiller drains are a great help in low spots that develop when a paddock settles. This settling process seems to be a continuing problem in the lower areas. The wheel tract\& type digger with the side-mounted hydraulic arm and bucket is an ideal draining machine. With its ability to clean just the bottom of drains, if that is all that is required, this has been a wonderful development. In fact, this digger machine cleans drains for less today than it cost to clean the same drains by hand back in 1948 .

Drainage should be only as deep as is essential, as it is very easy to over-drain in our mixed type of country. Cleaning of the drains should be left to as late in the autumn as possible to avoid 
autumn growth, and inefficiency in late spring. If you vall get surplus winter rain to run off as it arrives that is ideal!

\section{LAND LEVELLING}

In some areas impossible to drain, or where drainage would adversely affect another area, we use earthmoving machinery to move sandhil!s into swamps. This is a very easy way io write a large cheque, so serious consideration must be given and only a good operator employed. Often the area from which the fill has been removed remains infertile for a very long time. Theoretically it is ideal, but in practice a very expensive and complex operation.

Ail ${ }^{11}$ of the topsoil needs to be stripped. Tf 14 : 10 tapial coverud, we do not take the lupins off separately. Only as much as is practical should be opened so that the topsoil from the second piece covers the first, and is thus moved only once. Some operators place old hay or straw on the raw sand before recovering. About $300 \mathrm{~mm}$ of sand can be pushed on to a swamp area without stripping the area, and a plough will bring up enough peat to mix with the sand.

\section{PASTURES}

Mixtures used varied with different areas, but the basic seeds used today are $13 \mathrm{~kg}$ Nui ryegrass, $13 \mathrm{~kg}$ Manawa ryegrass, and $3 \mathrm{~kg}$ Huia white clover, a total of $29 \mathrm{~kg} / \mathrm{ha} .2 \mathrm{~kg}$ 'Grasslands Apanui' cocksfoot, $250 \mathrm{~g}$ Mt Barker subterranean clover, and $250 \mathrm{~g}$ Tallarook subterranean clover are added on sandy flats and low ridges.

The $37 \mathrm{~kg} / \mathrm{ha}$ mixture used on the higher sandhills was Ruanui ryegrass $17 \mathrm{~kg}$, Manawa ryegrass $9 \mathrm{~kg}$, Paroa Italian ryegrass $8 \mathrm{~kg}$, Apanui cocksfoot $6 \mathrm{~kg}$, crested dogstail $1 \mathrm{~kg}$, Hamua red clover $2 \mathrm{~kg}$, Huia white clover $2 \mathrm{~kg}$, Mt Barker subterranean clover $1 \mathrm{~kg}$ and Tallarook subterranean clover $1 \mathrm{~kg}$.

The red clover failed, as did the Paroa ryegrass, after the first year. The hills became very subterranean clover-dominant for about 10 years. With fertility and humus build-up, cocksfoot and ryegrass are playing a greater part in feed production. No hills have been reworked, and this will be avoided if possible. Some areas of the flats seem to require renovation after about 10 years, and this fits into the summer crop pattern, allowing for the introduction of new varieties. I still regard a summer forage crop as essential in our district. 


\section{TOPDRESSING}

The total developed area is topdressed each February with $375 \mathrm{~kg} \mathrm{30 \%}$ potassic superhosphate/ha, and those areas expectcd to be green in February are given another $375 \mathrm{~kg}$ of the same mixture in the first week of November. Amounts of $625 \mathrm{~kg}$ serpentine superphosphate are used at crop sowing, and again at the pasture establishment stage. About 40 ha receive nitrogen, $150 \mathrm{~kg}$ urea/ha in April to help winter feed build up.

\section{PESTS}

Grass Grubs

DDT every three years formerly controlled this curse. Today heavy stocking of affected areas in late autumn and early winter is practised. Cows at $180 / 0.5$ ha for 24 hours, with 30 bales of hay from good pasture, are deemed to be preferable to the new, costly, and often ineffective insecticides. In fact, wintering is carried out in this manner on all the hill areas.

\section{RABBITS}

As our property is near forest, so rabbits are still a problcm. Jack rabbit is a costly fellow to control by rating, and science does not scem to make much progress.

\section{SUPPLEMENTARY FEEDING}

Turnips are sown for use in January, February, and March. I-lay is made carly in December. We used to make silage, but, because of the change of calving patterns for town milk supply, grass grub control, and doubtless the advancing vears, hay is now preferred. Also a visit to France in 1974 really brought home to me how little I knew about quality silage production. If possible I would prefer to buy good hay — at a price!

\section{ANIMAL HEALTH}

Our soil is deficient in cobalt, copper, and selenium, and these deficiencies are corrected by using $140 \mathrm{~g}$ of cobalt/ha with the autumn topdressing. Copper injections are given to stock twice a year and selenium is injected into adult cattle, and included in all drenches to the younger stock.

\section{BLOAT}

Oil spraying of pasture is used for bloat control, and the inability to spray was one of the. limiting factors in not develop- 
ing the highest and steepest areas of the farm. With bloat drenching those areas may not appear so high or so steep. Again, I am hoping science will advance more quickly; an easier cc:ntrol of bloat in cattle is urgently needed.

\section{WATER SUPPLY}

In our district wells of the normal borehole type vary in depth from 15 to $150 \mathrm{~m}$. They vary also in flow per hour, and in iron and other mineral content. Many farmers rely on sandtrap type wells at a depth of 5 to $8 \mathrm{~m}$ in the running grey sand strata. These vary also in quantity and quality. The cost of irrigation outweighs the advantages even if quality water were available.

\section{GRAZING MANAGEMENT}

Rotational grazing with all its variations is practised. Broadly speaking, on a yearly basis our routine would be as follows.

Mid-May with autumn cows calving, we start on 40 ha of ureatreated pasture, plus 15 other paddocks expected to last until mid-July. A further 12 paddocks are then brought in and cows are on 12 hours to a field on a 21- to 25-day rotation. In early January, hay-aftermath paddocks and turnip crops are included, extending the rotation to as much as six weeks, depending on the season. In a dry season, some 24-hour grazing is practised. and a calculated drop in production accepted. In a more favourable season turnip feeding can be delayed and only the hay paddocks brought in, giving a 30-day, 12-hour feeding rotation.

Hay paddocks are taken out to be ready for cutting in early December and are replaced in the rotation by more hilly areas on which the dry stock were wintered. Some flexibility is used in grazing rotation, depending on how the season is going. A niggling gut feeling is sometimes the deciding factor of rotation interval. In general, I favour a long rotation.

\section{TODAY'S FARM}

In 1967 I purchased an adjoining 24 ha which had an 8 ha sandy ridge through it, covered in old-man giant lupin. In 1971 the drought played havoc with this newly developed area. and lupin reinfestation has been a problem. My son bought an adjoining 16 ha in 1972 and a further 45.5 ha in November 1975. We now farm in partnership, milking the herd through one shed. We milk a maximum of 270 cows, and have a 1237 litre daily 
town milk quota. We produced $41000 \mathrm{~kg}$ of milk fat last season and reared 100 bull calves in addition to normal herd replacements. The total farm area of 185.5 ha is now subdivided into 80 paddocks.

\section{TODAY'S DISTRICT}

Since 1946 the sandy area from Waitarere north to the Manawatu River has seen a change of many hundreds of acres from sheep to dairy farming, and only a few acres from dairying to sheep. The Waitarere State Forest of about 2100 ha is very productive, and has arrested much sand movement. Much of the land of the bigger sheep holdings is now under the control of forestry. Drainage has improved but the westerly winds still blow - soil fertility build-up is slow, and costly.

In summary - overall productivity has increased considerably, drainage and fertilizers being the key factors. It is my firm belief that any success in sand country farming comes from i combination - much hard work, good employees, stock control with intensive subdivision, farm roading, drainage, water reticulation, topdressing - lots of potassic superphosphate and a little expensive nitrogen at critical times, noticing what others are doing, discussions with them, and the help of farm advisers $\rightarrow$ and a considerate bank manager. Good luck can help, but do not bury your head in the sand and just hope. 